\title{
Role of Dietary, Adipose, and Endogenously Synthesized Fatty Acids in the Pathogenesis of the Alcoholic Fatty Liver*
}

\author{
Charles S. Lieber, $†$ Norton Spritz, $\ddagger$ and Leonore M. DeCarli \\ (From the Second [Cornell] Medical Division, Bellevue Hospital, and the Department of \\ Medicine, Cornell University Medical College, New York, N. Y.)
}

The fatty liver associated with alcoholism has been shown to be due not only to nutritional deficiencies (2) but also to direct effects of ethanol itself $(3,4)$. The origin of the fatty acids accumulating in the liver, however, remains the subject of much debate (4-7). Administration of a single large dose of ethanol to rats was found to result in the deposition in the liver of fatty acids similar in composition to adipose tissue, leading to the concept that increased peripheral fat mobilization is responsible for the alcoholic fatty liver (8). On the other hand, studies of the effect of ethanol on free fatty acid (FFA) concentrations $(9,10)$, arteriovenous differences across extremities (9), and FFA turnover (11) have indicated either no effect or even a decrease in peripheral fat mobilization. To resolve these differences, we undertook the present study in which direct comparison was made of the fatty acid compositions of liver and adipose tissue lipids after acute or prolonged ethanol intake with lowfat or fat-containing diets. It was confirmed that, in rats, the administration of a single large dose of

\footnotetext{
* Submitted for publication May 21, 1965 ; accepted September 23, 1965.

Presented at the Annual Meeting of the American Association for the Study of Liver Diseases, Chicago, November 6, 1964, and published in part in abstract form (1). Supported in part by U. S. Public Health Service research grant AM06284 from the National Institute of Arthritis and Metabolic Diseases and grant NB03346-04 from the National Institute of Neurological Diseases and Blindness.

† Recipient of U. S. Public Health Service Research Career Development Award K3-AM-22, 590 from the National Institute of Arthritis and Metabolic Diseases.

Address requests for reprints to Dr. Charles S. Lieber, Second (Cornell) Medical Division, Bellevue Hospital, 1st Ave. and 26th St., New York, N. Y. 10016.

$\ddagger$ Established Investigator of the Health Research Council of New York (I-128).
}

ethanol leads to hepatic accumulation of fatty acids resembling those of adipose tissue. In contrast, prolonged ethanol ingestion produced fatty livers with fatty acid compositions strikingly different from adipose tissue, consisting of endogenously synthesized fatty acids and, when available, dietary fatty acids. Elimination of the dietary fatty acids with isocaloric replacement by sucrose was found to reduce the amount of fat accumulation in the liver on prolonged alcohol ingestion.

\section{Methods}

\section{A). Diets and procedure}

Sprague-Dawley CD male or female rats were purchased in groups of six weanling littermates. ${ }^{1}$ They were fed Purina laboratory chow and tap water ad libitum until the period of study, when they were housed in individual bottom-wired cages. The Purina chow used had a caloric value of about 340 calories per $100 \mathrm{~g}$, as calculated from the data of the manufacturer; its total lipid content was $6 \%$, with $30 \%$ of fatty acids as linoleate $(18: 2)$ as determined in our laboratory. At the end of the experiment, the rats were sacrificed by decapitation, blood was collected from the neck vessels in heparinized tubes, and plasma was obtained by immediate centrifugation in the cold. The various organs were quickly excised and the tissues stored at $-18^{\circ} \mathrm{C}$ until analysis.

Administration of a single large dose of ethanol. Seven pairs of male rats and five pairs of female rats weighing 150 to $250 \mathrm{~g}$ were fasted for 8 hours and then given by gastric tube $7.5 \mathrm{~g}$ per $\mathrm{kg}$ ethanol in a $50 \%$ solution in water or isocaloric amounts of glucose and sacrificed 16 hours thereafter.

Prolonged ethanol intake with low-fat and fat-containing diets. Forty-four male rats weighing approximately 100 to $150 \mathrm{~g}$ were fed for 24 days in groups of four littermates with isocaloric amounts of liquid diets as the only sources of food or water. The technique of pair-feeding and the composition of the diets were as described before (3), except for the oil mixture, which consisted, in the fat-containing diets $(43 \%$ of total calo-

\footnotetext{
${ }^{1}$ Charles River Breeding Laboratories, North Wilmington, Mass.
} 
TABLE I

Fatty acid composition of liquid diets containing coconut and linseed oil*

\begin{tabular}{|c|c|c|c|c|c|c|c|c|}
\hline Diet & $\begin{array}{c}8: 0 \\
+10: 0\end{array}$ & $\begin{array}{c}12: 0 \\
+14: 0\end{array}$ & $16: 0$ & $16: 1$ & $18: 0$ & $18: 1$ & $18: 2$ & $18: 3$ \\
\hline & \multicolumn{8}{|c|}{$\%$ of total composition } \\
\hline Coconut & 9.0 & 50.8 & 26.9 & & 1.9 & 5.6 & 5.6 & \\
\hline Linseed & & & 6.7 & & 3.0 & 20.1 & 19.5 & 50.5 \\
\hline
\end{tabular}

* Acíds designated as chain length: double bond (13).

ries), of $2.0 \mathrm{~g}$ per $\mathrm{L}$ ethyl linoleate (supplemented with vitamin A acetate, $2 \mathrm{mg}$ per L; calciferol, $10 \mu \mathrm{g}$ per L; alpha tocopherol acetate, $30 \mathrm{mg}$ per $\mathrm{L}), 10.0 \mathrm{~g}$ per $\mathrm{L}$ corn oil, and $34.25 \mathrm{~g}$ per $\mathrm{L}$ olive oil. In the low-fat diets the oils were isocalorically replaced with sucrose except for the ethyl linoleate ( $2 \%$ of total calories), which was maintained to avoid essential fatty acid deficiency (12). With each type of diet, one rat received the control sucrose diet, whereas its littermate was given the same diet in which sucrose, to the extent of $36 \%$ of calories, was isocalorically replaced with ethanol to produce a fatty liver (3). It has been shown previously that this type of fatty liver is due to ethanol itself and not to the decrease in carbohydrate in the fat-containing diet, because simple omission of the carbohydrate calories, or their replacement with additional fat, leading to a diet with $79 \%$ of calories as fat, did not produce fatty liver in the absence of ethanol (3).

To "prelabel" adipose tissue, 12 male rats weighing from 60 to $90 \mathrm{~g}$ were given ad libitum sucrose liquid diets in which the regular corn-olive oil mixture was changed to either $44.25 \mathrm{~g}$ per $\mathrm{L}$ linseed oil (six rats), or $44.25 \mathrm{~g}$ per $\mathrm{L}$ coconut oil (six rats). Preliminary studies indicated that when given with ethanol, these diets produced a degree of hepatic steatosis similar to the one observed with the olive-corn oil mixture. The fatty acid composition of these diets is indicated in Table I. Fifty and eight-tenths per cent of the fatty acids of the coconut oil diet was composed of laurate $(12: 0)$ and myristate $(14: 0)$, which were only present in trace amounts in linseed oil; conversely linolenate $(18: 3)$, which comprised $50.5 \%$ of the fatty acids of the linseed oil diet, was absent from the coconut oil diet. Weekly adipose tissue biopsies indicated that after 21 days, more than $30 \%$ of adipose fatty acids were comprised of laurate (12:0) and myristate $(14: 0)$, or linolenate $(18: 3)$ in the rats fed coconut or linseed oil diets, respectively, compared to about $50 \%$ in the dietary fat (Table I) and under $2 \%$ in adipose tissue of the rats that had been on the Purina chow diet (Table II). The rats had, on the average, doubled their weights. At that time, sucrose, to the extent of $36 \%$ of total calories, was isocalorically replaced by ethanol in half the rats. Simultaneously, to differentiate adipose tissue from dietary fatty acids, we switched coconut oil of the liquid diets to linseed oil and vice versa. Each alcohol rat was individually pairfed twice a day with its respective sucrose control littermate, and after 11 days, the rats were sacrificed, and various tissues, including epididymal fat pads, were collected and stored for processing.

TABLE II

Effect of a single dose of ethanol* or isocaloric glucose on fatty acid composition in liver triglycerides, adipose tissue lipids, and plasma FFA of male and female rats

\begin{tabular}{|c|c|c|c|c|c|c|c|c|c|}
\hline \multirow[b]{2}{*}{ Sex } & \multirow[b]{2}{*}{ Treatment } & & \multicolumn{7}{|c|}{ Fatty acid composition } \\
\hline & & & $\begin{array}{l}12: 0 \\
+14: 0\end{array}$ & $16: 0$ & $16: 1$ & $18: 0$ & $18: 1$ & $18: 2$ & $18: 3$ \\
\hline & & & \multicolumn{7}{|c|}{$\%$ of total composition } \\
\hline Male & Ethanol & $\begin{array}{l}\text { Liver triglycerides }(16.2 \mathrm{mg} / \mathrm{g}) \\
\text { Adipose tissue lipids } \\
\text { Plasma FFA }(1.19 \mathrm{mEq} / \mathrm{L})\end{array}$ & $\begin{array}{l}1.2 \\
1.5\end{array}$ & $\begin{array}{l}24.2 \\
16.1 \\
24.1\end{array}$ & $\begin{array}{l}5.0 \\
5.4 \\
5.6\end{array}$ & $\begin{array}{r}6.0 \\
4.9 \\
10.5\end{array}$ & $\begin{array}{l}36.0 \\
44.9 \\
36.6\end{array}$ & $\begin{array}{l}27.6 \\
25.9 \\
23.3\end{array}$ & \multirow[t]{2}{*}{1.3} \\
\hline Male & Ethanol & $\begin{array}{l}\text { Liver triglycerides }(10.7 \mathrm{mg} / \mathrm{g}) \\
\text { Adipose tissue lipids }\end{array}$ & $\begin{array}{l}1.6 \\
1.9\end{array}$ & $\begin{array}{l}21.8 \\
20.9\end{array}$ & $\begin{array}{l}4.9 \\
7.7\end{array}$ & $\begin{array}{l}4.9 \\
5.5\end{array}$ & $\begin{array}{l}32.2 \\
36.2\end{array}$ & $\begin{array}{l}34.4 \\
27.7\end{array}$ & \\
\hline Male† & Glucose & $\begin{array}{l}\text { Liver triglycerides }(2.9 \mathrm{mg} / \mathrm{g}) \\
\text { Adipose tissue lipids }\end{array}$ & $\begin{array}{l}1.6 \\
1.4\end{array}$ & $\begin{array}{l}26.8 \\
19.9\end{array}$ & $\begin{array}{l}4.1 \\
8.9\end{array}$ & $\begin{array}{l}7.3 \\
6.3\end{array}$ & $\begin{array}{l}27.6 \\
33.1\end{array}$ & $\begin{array}{l}32.5 \\
28.6\end{array}$ & \multirow[t]{2}{*}{1.8} \\
\hline Female & Ethanol & $\begin{array}{l}\text { Liver triglycerides }(11.3 \mathrm{mg} / \mathrm{g}) \\
\text { Adipose tissue lipids } \\
\text { Plasma FFA }(0.64 \mathrm{mEq} / \mathrm{L})\end{array}$ & $\begin{array}{l}1.1 \\
2.4\end{array}$ & $\begin{array}{l}27.1 \\
19.9 \\
29.9\end{array}$ & $\begin{array}{l}5.9 \\
9.6 \\
6.8\end{array}$ & $\begin{array}{l}6.6 \\
6.0 \\
6.8\end{array}$ & $\begin{array}{l}39.0 \\
37.0 \\
36.8\end{array}$ & $\begin{array}{l}20.8 \\
24.7 \\
19.7\end{array}$ & \\
\hline Female & Ethanol & $\begin{array}{l}\text { Liver triglycerides }(43.4 \mathrm{mg} / \mathrm{g}) \\
\text { Adipose tissue lipids } \\
\text { Plasma FFA }(0.68 \mathrm{mEq} / \mathrm{L})\end{array}$ & $\begin{array}{l}0.9 \\
0.2\end{array}$ & $\begin{array}{l}26.3 \\
23.6 \\
26.6\end{array}$ & $\begin{array}{l}3.6 \\
5.9 \\
5.3\end{array}$ & $\begin{array}{l}2.8 \\
5.9 \\
4.0\end{array}$ & $\begin{array}{l}45.2 \\
41.9 \\
45.2\end{array}$ & $\begin{array}{l}21.4 \\
19.4 \\
18.6\end{array}$ & \multirow[t]{2}{*}{0.9} \\
\hline Female $†$ & Glucose & $\begin{array}{l}\text { Liver triglycerides }(3.4 \mathrm{mg} / \mathrm{g}) \\
\text { Adipose tissue lipids } \\
\text { Plasma FFA }(0.67 \mathrm{mEq} / \mathrm{L})\end{array}$ & $\begin{array}{l}0.8 \\
2.1\end{array}$ & $\begin{array}{l}28.3 \\
21.9 \\
31.7\end{array}$ & $\begin{array}{r}3.2 \\
8.4 \\
13.5\end{array}$ & $\begin{array}{r}4.2 \\
6.4 \\
10.4\end{array}$ & $\begin{array}{l}37.0 \\
39.4 \\
32.8\end{array}$ & $\begin{array}{l}26.5 \\
18.0 \\
11.4\end{array}$ & \\
\hline
\end{tabular}

* $7.5 \mathrm{~g}$ per $\mathrm{kg}$.

$\dagger$ The two male rats indicated were littermates, and the two female rats indicated were littermates. 
Metabolism of dietary lipids. Eighteen pairs of rats (150 to $250 \mathrm{~g}$ ) that had been maintained on Purina chow were given, after an overnight fast, $60 \mathrm{ml}$ per $\mathrm{kg}$ of the coconut liquid diet (either ethanol or control), supplemented with $0.5 \mu \mathrm{c}$ per $\mathrm{ml}$ of tritiated palmitate, ${ }^{2}$ by gastric tube. The animals were sacrificed after various periods of time; the gastrointestinal tract (from cardia to rectum) and the liver were excised for determination of total lipid labeling.

Chylomicrons ${ }^{-14} \mathrm{C}$ were obtained in rats fed coconut diet supplemented with $10 \mu \mathrm{c}$ per $\mathrm{ml}^{14} \mathrm{C}$-labeled palmitate, ${ }^{3}$ initially by the technique of Green and Webb (14) without the use of heparin, and subsequently, to minimize alteration of chylomicrons, by thoracic duct cannulation by a modification of the technique of Bollman, Cain, and Grindlay (15) and collection of lymph at room temperature. The lymph was allowed to clot, the supernatant was added to rat serum diluted with saline $(1: 1)$, and the chylomicrons were isolated in the top fraction after ultracentrifugation in a Spinco ultracentrifuge for 20 minutes at $87,000 \mathrm{~g}$ at room temperature (16). In all instances, more than $90 \%$ of the labeling was in the triglycerides. Five-tenths to one $\mathrm{ml}$ of the chylomicron $-{ }^{14} \mathrm{C}$ containing supernatant fraction was injected in a tail vein in 17 pairs of rats 2 to 3 hours after intubation with the coconut liquid diet. The injected chylomicrons represented a triglyceride load of approximately $4 \mathrm{mg}$ when obtained by the method of Green and Webb (14) and from 4 to $10 \mathrm{mg}$ when obtained by thoracic duct cannulation. The rats were sacrificed either 10 minutes or 3 hours after chylomicron injection. In six pairs of rats, the chylomicrons $-{ }^{14} \mathrm{C}$ were injected into a femoral vein under light ether anesthesia, and blood was collected from the tail veins repeatedly during the 10 to $15 \mathrm{~min}$ utes after the injection.

\section{B) Chemical assays}

Extraction. Lipid extraction of homogenized liver, gut including luminal contents, and whole blood or plasma was carried out by the method of Folch, Lees, and Sloane Stanley (17). The extract utilized for plasma free fatty acids was obtained by the method of Dole (18). Adipose tissue was minced in ethanol: diethyl ether $(3: 1)$, which was evaporated in a nitrogen atmosphere and the residue dissolved in petroleum ether, bp 30 to $60^{\circ} \mathrm{C}$.

Total lipids. Total lipids were determined gravimetrically after evaporation of the solvent under nitrogen and drying in a dessicator until constant weight of the dried lipid was achieved.

Liver triglyceride. The extract of liver lipid was evaporated and quantitatively transferred to a $2-\mathrm{g}$ silicic acid ${ }^{4}$ column in ethyl ether. Triglyceride without phospholipid was completely eluted with $30 \mathrm{ml}$ of diethyl

2 Purchased from New England Nuclear Corporation, Boston, Mass., as palmitic- $9,10-{ }^{3} \mathrm{H}$ acid, specific activity $315 \mathrm{mc}$ per mmole.

3 Purchased from New England Nuclear Corporation as palmitic- $1{ }^{14} \mathrm{C}$ acid, specific activity $23.5 \mathrm{mc}$ per mmole. 4 Bio-Rad Laboratories, Richmond, Calif. ether (EE). This eluate was evaporated and glycerol determined by the method of Van Handel and Zilversmit (19).

Preparation of material for gas-liquid chromatographic ( $G L C$ ) analyses. 1) Liver triglyceride. Triglyceride was isolated from the liver lipid extract for GLC by thin-layer chromatography. Phospholipid was first removed by column chromatography as described above. The EE eluate containing about $15 \mathrm{mg}$ of lipid was applied in multiple applications to a $0.5-\mathrm{mm}$ silicic acid chromatoplate that had been prerun with methanol: EE, $1: 1$. The plate was developed in heptane:EE: acetic acid, $60: 39: 1$, and the triglyceride area eluted by the method of Goldrick and Hirsch (20). Hydrolysis was carried out in $0.1 \mathrm{~N} \mathrm{KOH}$ in $70 \%$ ethanol at $60^{\circ} \mathrm{C}$ for 30 minutes. After acidification, the fatty acids were extracted into petroleum ether, which was evaporated; methylation was carried out with boron trifluoride methanol (21).

2) Adipose tissue lipids. The extract of adipose tissue was evaporated, and hydrolysis and methylation were carried out as above.

3) Free fatty acids. FFA were isolated from the extract of plasma by a two-column procedure. An internal standard of pentadecanoic acid $(15: 0)^{5}$ was added to the extract of 0.5 to $2.0 \mathrm{ml}$ of plasma, which was then evaporated under nitrogen and applied with $2 \mathrm{ml}$ of $\mathrm{EE}$ to a $2-\mathrm{g}$ silicic acid column. Thirty $\mathrm{ml}$ of $\mathrm{EE}$ quantitatively eluted fatty acid and neutral lipid. This eluate was evaporated under nitrogen and in a small volume reapplied to a 2-g Florisil 6 column, which was prerun with $50 \mathrm{ml}$ methanol: acetic acid $(99: 1)$ and then $100 \mathrm{ml} \mathrm{EE}$. Neutral lipids were removed with $30 \mathrm{ml} \mathrm{EE}$ and FFA in a second elution of $30 \mathrm{ml}$ acetic acid: $\operatorname{EE~}(1: 99)$. The latter was evaporated under nitrogen, and the methyl esters were prepared. The method was verified by running a blank containing only 15:0, and no artefactual peaks were noted on the chromatography; by quantitative recovery of lauric acid (12:0) added to the initial plasma extract; and by the absence of radioactivity in the methyl ester solution when triglyceride and cholesterol ester labeled in fatty acid ${ }^{5}$ were added to the initial extract.

Gas-liquid chromatographic analyses. All specimens to be chromatographed were stored under nitrogen at $4^{\circ} \mathrm{C}$. An $\mathrm{F}$ and $\mathrm{M}$ model 400 chromatograph with a six-foot diethyleneglycoladipate column at $200^{\circ} \mathrm{C}$ with a flame ionization detector was utilized. The instrument was standardized with solutions of fatty acid standards $A$ to $E, 7$ and recovery of major components was within $2 \%$ (22). Arachidonic (20:4), linolenic (18:3), and lauric $(12: 0)$ acids were carried through all preparative steps with duplicate portions of specimens, and recovery exceeded $95 \%$ in all instances.

Determination of radioactivity. Determinations of ${ }^{14} \mathrm{C}$ and ${ }^{3} \mathrm{H}$ were carried out in a Tri-carb liquid scintillation counter as described before (22).

\footnotetext{
5 Applied Science Laboratories, State College, Pa.

6 Floridin Co., Tallahassee, Fla.

${ }^{7}$ National Institutes of Health, Bethesda, Md.
} 
Statistical analyses. In all experiments, each result was compared to the corresponding control, and the mean of the individual differences was tested by the Student $t$ test (23).

\section{Results}

Effect of a single large dose of ethanol on hepatic lipids. Sixteen hours after the administration of a single large dose of ethanol, five female rats had an average total hepatic lipid of $81.0 \pm 3.3 \mathrm{mg}$ per $\mathrm{g}$, compared to $46.8 \pm 1.4 \mathrm{mg}$ per $\mathrm{g}$ in the control littermates given isocaloric amounts of glucose $(p<0.001)$. In the seven male rats given ethanol, total hepatic lipid accumulation was much smaller: $55.3 \pm 2.1 \mathrm{mg}$ per $\mathrm{g}$ versus $45.0 \pm 0.8$ $\mathrm{mg}$ per $\mathbf{g}$ in the glucose controls $(\mathrm{p}<0.01)$. In the six rats in which fatty acid compositions of liver triglycerides, adipose tissue lipids, and FFA were determined, they were found to be generally similar (Table II).
Effect of prolonged intake of ethanol with lowfat (2\% of calories) and fat-containing (43\% of calories) diets. As indicated in Figure 1, there was a significant increase of hepatic lipids on prolonged intake of ethanol with low-fat as well as with fat-containing diets. The increase in total hepatic lipids was due primarily to a rise in triglycerides. Hepatic lipid accumulation was significantly greater with the same amount of ethanol and the $43 \%$ fat-containing diets than with isocaloric amounts of the $2 \%$ low-fat diets (Figure 1). Compared to the controls, the rise in total hepatic lipids produced by ethanol was 2.6-fold with the $43 \%$ fat diet but only 1.5 -fold with the $2 \%$ fat diet $(\mathrm{p}<0.01)$; the corresponding changes in triglycerides were 6.3- and 2.6-fold, respectively $(p<0.05)$. The hepatic lipids of the sucrose control rats were higher with low-fat than with fat-containing diets (Figure 1, total lipids $\mathrm{p}>0.1$;

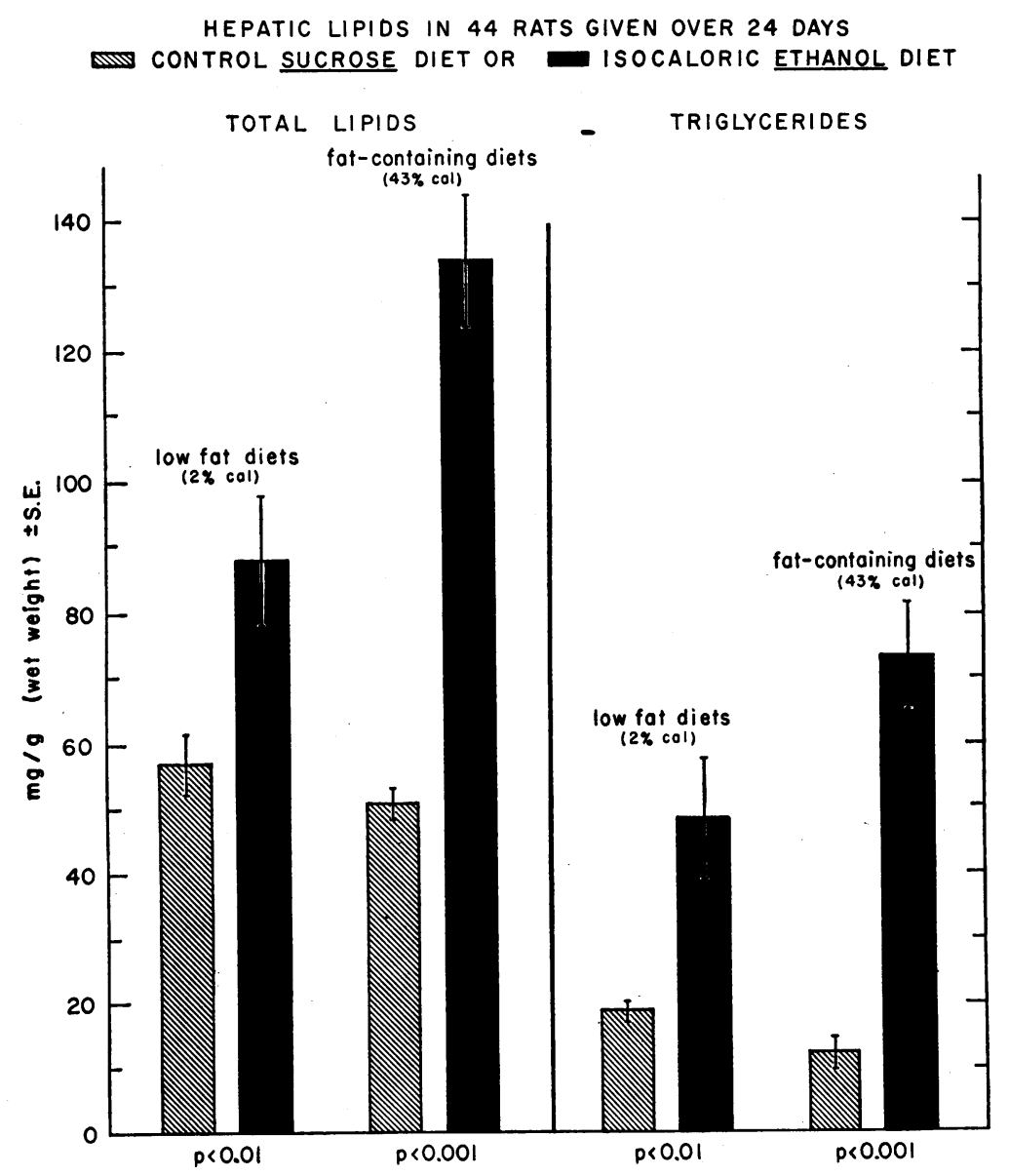

Fig. 1. Comparison of hepatic Steatosis PRODUCEd With DIETS OF VARYING FAT BUT CONSTANT ETHANOL CONTENTS. 


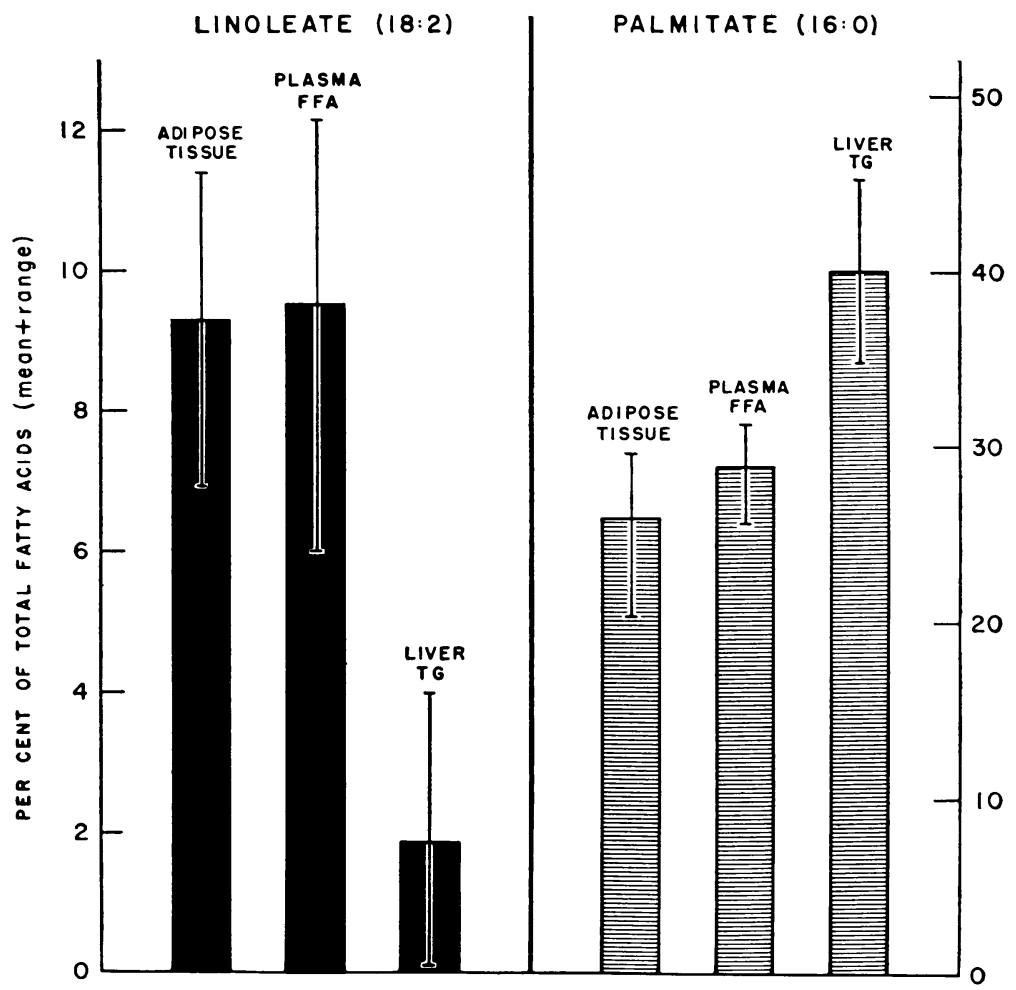

Fig. 2. Fatty acid composition in adipose tissle, plasia FFa, and LIVER TRIGLYCERIDES (TG) OF FOLR RATS THAT DEVELOPED FATTY LIVER AFTER 24 DAYS OF ETHANOL AND LOW-FAT (2\% OF CALORIES) DIET.

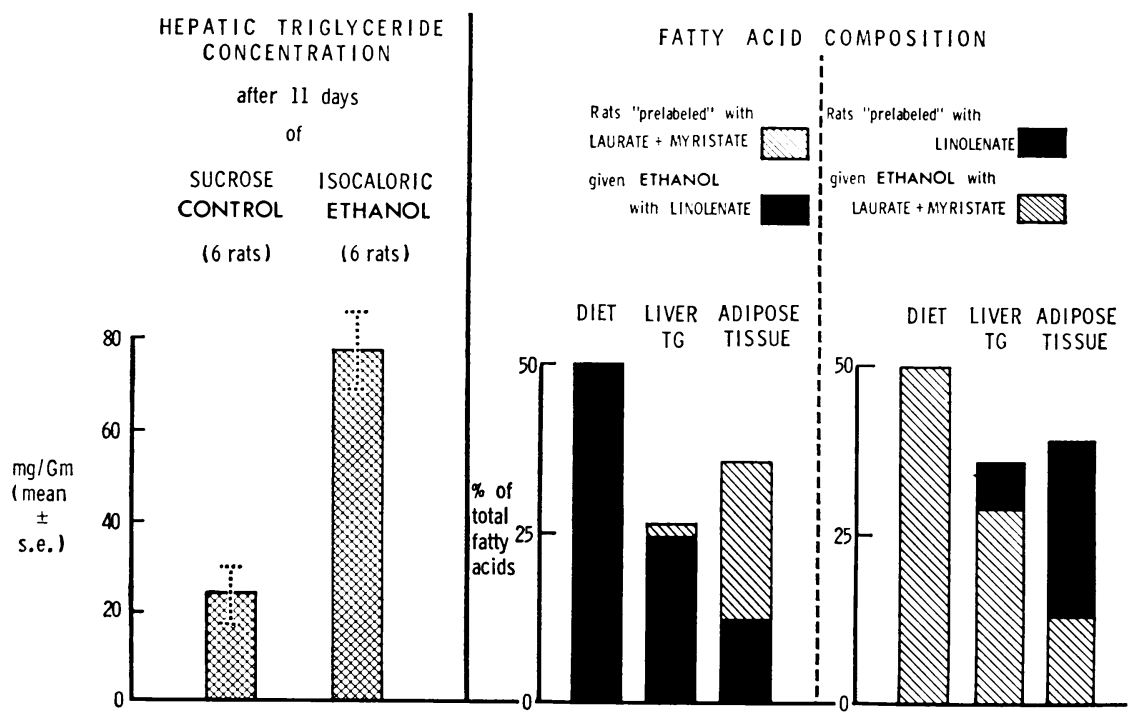

Fig. 3. Role of dietary fatty acids in hepatic triglyceride acclallation AFTER 11 DAYS OF ETHANOL. The concentrations of the characteristic dietary fatty acids linolenate and laurate plus myristate have been measured in liver triglycerides and adipose tissue lipids. 
triglycerides $\mathrm{p}<0.05$ ). Both groups had higher liver lipid contents than the control rats of the acute experiments.

In the four pairs in which the most pronounced fatty livers were obtained on low-fat ethanol diets, fatty acid compositions of liver triglycerides and adipose lipids were determined (Figure 2). In all instances there was a difference between adipose and liver triglyceride contents of linoleate $(18: 2)$ and palmitate $(16: 0)$ with, on the average, $50 \%$ more palmitate in liver triglyceride, whereas its linoleate concentration was one-fifth that of adipose tissue. The linoleate $(18: 2)$ content of FFA was also higher than in the liver, and approximated that of adipose tissue. The linoleate $(18: 2)$ content of adipose tissue was lower in the chronic than in the acute experiments (Figure 2 and Table II), which most likely reflects the fact that the linoleate $(18: 2)$ content of the low-fat liquid diet was about one-third that of the Purina chow fed before the acute experiments.

To determine the origin of the fatty acids of liver triglyceride in rats fed ethanol with fat-containing diets, and to differentiate dietary from adi-

TABLE III

Isotopic labeling of total hepatic lipids in rats sacrificed 2 to 6 hours after intubation with liquid diets containing ethanol or isocaloric sucrose and palmitate- ${ }^{3} H$

\begin{tabular}{|c|c|c|c|c|c|}
\hline Litter & $\begin{array}{l}\text { Palmitate-3H } \\
\text { administered }\end{array}$ & $\begin{array}{c}\text { Hours } \\
\text { after } \\
\text { intubation }\end{array}$ & Treatment & $\begin{array}{c}\text { Liver } \\
\text { weight }\end{array}$ & $\begin{array}{l}\text { Labeling of } \\
\text { total hepatic } \\
\text { lipids }\end{array}$ \\
\hline & $d p m \times 10^{3}$ & & & $g$ & $d p m / g$ \\
\hline 1 & 16,400 & 2 & $\begin{array}{l}\text { Ethanol } \\
\text { Sucrose }\end{array}$ & $\begin{array}{l}7.1 \\
6.7\end{array}$ & $\begin{array}{l}57,520 \\
55,870\end{array}$ \\
\hline 2 & 25,500 & 2 & $\begin{array}{l}\text { Ethanol } \\
\text { Sucrose }\end{array}$ & $\begin{array}{l}7.7 \\
7.0\end{array}$ & $\begin{array}{l}29,940 \\
43,190\end{array}$ \\
\hline 3 & 36,400 & $2 \frac{1}{4}$ & $\begin{array}{l}\text { Ethanol } \\
\text { Sucrose }\end{array}$ & $\begin{array}{l}10.9 \\
11.0\end{array}$ & $\begin{array}{l}54,550 \\
21,620\end{array}$ \\
\hline 4 & 30,900 & $2 \frac{1}{4}$ & $\begin{array}{l}\text { Ethanol } \\
\text { Sucrose }\end{array}$ & $\begin{array}{r}10.2 \\
7.4\end{array}$ & $\begin{array}{l}76,500 \\
47,990\end{array}$ \\
\hline 5 & 20,900 & $2 \frac{1}{2}$ & $\begin{array}{l}\text { Ethanol } \\
\text { Sucrose }\end{array}$ & $\begin{array}{l}6.1 \\
5.7\end{array}$ & $\begin{array}{l}57,390 \\
31,820\end{array}$ \\
\hline 6 & 18,200 & $2 \frac{3}{4}$ & $\begin{array}{l}\text { Ethanol } \\
\text { Sucrose }\end{array}$ & $\begin{array}{l}5.9 \\
5.3\end{array}$ & $\begin{array}{r}115,060 \\
45,790\end{array}$ \\
\hline 7 & 29,100 & $2 \frac{3}{4}$ & $\begin{array}{l}\text { Ethanol } \\
\text { Sucrose }\end{array}$ & $\begin{array}{l}11.0 \\
11.7\end{array}$ & $\begin{array}{l}45,030 \\
22,220\end{array}$ \\
\hline 8 & 16,400 & 3 & $\begin{array}{l}\text { Ethanol } \\
\text { Sucrose }\end{array}$ & $\begin{array}{l}5.1 \\
5.1\end{array}$ & $\begin{array}{l}77,320 \\
37,900\end{array}$ \\
\hline 9 & 29,100 & 3 & $\begin{array}{l}\text { Ethanol } \\
\text { Sucrose }\end{array}$ & $\begin{array}{l}8.4 \\
9.1\end{array}$ & $\begin{array}{l}61,510 \\
27,840\end{array}$ \\
\hline 10 & 21,600 & 4 & $\begin{array}{l}\text { Ethanol } \\
\text { Sucrose }\end{array}$ & $\begin{array}{l}7.0 \\
7.1\end{array}$ & $\begin{array}{l}109,330 \\
103,330\end{array}$ \\
\hline 11 & 27,300 & 5 & $\begin{array}{l}\text { Ethanol } \\
\text { Sucrose }\end{array}$ & $\begin{array}{l}8.7 \\
9.6\end{array}$ & $\begin{array}{r}140,850 \\
64,130\end{array}$ \\
\hline 12 & 34,600 & 5 & $\begin{array}{l}\text { Ethanol } \\
\text { Sucrose }\end{array}$ & $\begin{array}{l}10.5 \\
10.5\end{array}$ & $\begin{array}{l}55,070 \\
41,050\end{array}$ \\
\hline 13 & 25,500 & 5 & $\begin{array}{l}\text { Ethanol } \\
\text { Sucrose }\end{array}$ & $\begin{array}{l}10.9 \\
10.7\end{array}$ & $\begin{array}{l}53,300 \\
22,570\end{array}$ \\
\hline 14 & 22,500 & 5 & $\begin{array}{l}\text { Ethanol } \\
\text { Sucrose }\end{array}$ & $\begin{array}{l}8.0 \\
8.6\end{array}$ & $\begin{array}{l}70,110 \\
38,380\end{array}$ \\
\hline 15 & 18,900 & $5 \frac{1}{2}$ & $\begin{array}{l}\text { Ethanol } \\
\text { Sucrose }\end{array}$ & $\begin{array}{l}5.6 \\
6.7\end{array}$ & $\begin{array}{r}74,640 \\
100,970\end{array}$ \\
\hline 16 & 30,900 & $5 \frac{3}{4}$ & $\begin{array}{l}\text { Ethanol } \\
\text { Sucrose }\end{array}$ & $\begin{array}{r}9.8 \\
10.1\end{array}$ & $\begin{array}{l}34,990 \\
81,680\end{array}$ \\
\hline 17 & 30,900 & $5 \frac{3}{4}$ & $\begin{array}{l}\text { Ethanol } \\
\text { Sucrose }\end{array}$ & $\begin{array}{l}8.2 \\
9.8\end{array}$ & $\begin{array}{l}55,140 \\
46,070\end{array}$ \\
\hline 18 & 25,500 & 6 & $\begin{array}{l}\text { Ethanol } \\
\text { Sucrose }\end{array}$ & $\begin{array}{l}8.9 \\
8.5\end{array}$ & $\begin{array}{r}131,400 \\
69,520\end{array}$ \\
\hline
\end{tabular}


TABLE IV

Isotopic labeling of total hepatic lipids and plasma triglycerides 3 hours after iv injection of chylomicrons-14C and 5 to 6 hours after intubation with ethanol- or sucrose-containing diets

\begin{tabular}{|c|c|c|c|c|c|c|c|}
\hline \multirow[b]{2}{*}{ Litter } & \multirow{2}{*}{$\begin{array}{l}\text { Chylomi- } \\
\text { crons-14C } \\
\text { injected }\end{array}$} & \multirow[b]{2}{*}{ Treatment } & \multirow[b]{2}{*}{$\begin{array}{c}\text { Liver } \\
\text { weight }\end{array}$} & \multirow{2}{*}{$\begin{array}{l}\text { Labeling } \\
\text { of total } \\
\text { hepatic } \\
\text { lipids }\end{array}$} & \multicolumn{3}{|c|}{ Plasma triglycerides } \\
\hline & & & & & & & $\begin{array}{l}\text { Specific } \\
\text { activity }\end{array}$ \\
\hline & $d p m \times 10^{5}$ & & $g$ & $d p m / g$ & $m g / 100 \mathrm{ml}$ & $d p m / 100 m l$ & $d p m / m g$ \\
\hline 1 & $3.14^{*}$ & $\begin{array}{l}\text { Ethanol } \\
\text { Sucrose }\end{array}$ & $\begin{array}{l}8.9 \\
8.5\end{array}$ & $\begin{array}{r}11,070 \\
7,980\end{array}$ & $\begin{array}{l}51.0 \\
51.9\end{array}$ & $\begin{array}{l}11,600 \\
11,600\end{array}$ & $\begin{array}{l}226 \\
224\end{array}$ \\
\hline 2 & $4.71^{*}$ & $\begin{array}{l}\text { Ethanol } \\
\text { Sucrose }\end{array}$ & $\begin{array}{l}8.7 \\
9.6\end{array}$ & $\begin{array}{l}12,570 \\
10,190\end{array}$ & $\begin{array}{l}64.0 \\
44.8\end{array}$ & $\begin{array}{l}21,800 \\
12,800\end{array}$ & $\begin{array}{l}341 \\
286\end{array}$ \\
\hline 3 & 7.83 & $\begin{array}{l}\text { Ethanol } \\
\text { Sucrose }\end{array}$ & $\begin{array}{r}9.8 \\
10.1\end{array}$ & $\begin{array}{r}9,010 \\
10,656\end{array}$ & $\begin{array}{r}105.9 \\
95.4\end{array}$ & $\begin{array}{l}31,400 \\
26,800\end{array}$ & $\begin{array}{l}297 \\
281\end{array}$ \\
\hline 4 & 7.83 & $\begin{array}{l}\text { Ethanol } \\
\text { Sucrose }\end{array}$ & $\begin{array}{l}10.5 \\
10.5\end{array}$ & $\begin{array}{l}17,490 \\
10,650\end{array}$ & & & \\
\hline 5 & 8.50 & $\begin{array}{l}\text { Ethanol } \\
\text { Sucrose }\end{array}$ & $\begin{array}{l}8.2 \\
9.8\end{array}$ & $\begin{array}{r}10,180 \\
8,410\end{array}$ & $\begin{array}{l}45.2 \\
98.3\end{array}$ & $\begin{array}{l}25,600 \\
28,200\end{array}$ & $\begin{array}{l}566 \\
287\end{array}$ \\
\hline 6 & $\cdot 13.67$ & $\begin{array}{l}\text { Ethanol } \\
\text { Sucrose }\end{array}$ & $\begin{array}{l}7.0 \\
7.1\end{array}$ & $\begin{array}{l}52,040 \\
35,770\end{array}$ & & & \\
\hline 7 & 13.67 & $\begin{array}{l}\text { Ethanol } \\
\text { Sucrose }\end{array}$ & $\begin{array}{l}5.6 \\
6.7\end{array}$ & $\begin{array}{l}44,530 \\
30,770\end{array}$ & & & \\
\hline 8 & 13.67 & $\begin{array}{l}\text { Ethanol } \\
\text { Sucrose }\end{array}$ & $\begin{array}{l}5.9 \\
5.8\end{array}$ & $\begin{array}{l}23,670 \\
17,170\end{array}$ & $\begin{array}{l}43.1 \\
77.0\end{array}$ & $\begin{array}{l}37,800 \\
97,200\end{array}$ & $\begin{array}{r}877 \\
1,262\end{array}$ \\
\hline
\end{tabular}

* Chylomicrons obtained by the method of Green and Webb (14). In all other experiments, the chylomicrons were obtained by thoracic duct cannulation.

pose fatty acids, we studied another group of rats. Fatty acid composition of liver triglyceride and adipose tissue lipids was determined in rats whose adipose tissue had been prelabeled by feeding one of two characteristic oils (coconut or linseed) followed by the administration of ethanol and ingestion of the other oil as described in Methods. As illustrated in Figure 3, ethanol ingestion resulted in a threefold increase of hepatic triglycerides. The fatty acid composition of the liver triglycerides accumulated on alcohol ingestion was strikingly different from adipose tissue with, on the average, a concentration of the prelabeling fatty acids one-sixth that of adipose tissue, whereas the concentration of the characteristic fatty acids fed with the ethanol was at least twice as high in liver triglycerides as in adipose tissue. These findings were observed regardless of the order in which oils were administered. In two rats, fatty acid composition of plasma FFA was determined and found to resemble the diet.

Effect of ethanol on the metabolism of dietary lipids and chylomicrons. a) Dietary lipids. As indicated in Table III, in 15 out of 18 pairs of rats given a single feeding of liquid diets with palmitate- ${ }^{3} \mathrm{H}$, more labeling was found in the liver lipids of rats given ethanol than in pair-fed sucrose control rats $(p<0.01)$. No significant difference was found, however, in the amount of total lipid labeling remaining in the gut wall and lumen (on the average, $11,500 \times 10^{3} \mathrm{dpm}$ in the ethanol group and $13,700 \times 10^{3} \mathrm{dpm}$ in the controls; mean difference $2,200 \pm 1,300 \times 10^{3} \mathrm{dpm}, \mathrm{p}>0.1$ ). This suggested that the increase in liver labeling may not have resulted from a primary effect of ethanol on lipid absorption; a small difference in absorption, however, could have been masked by the large variation of the lipid labeling remaining in the gut.

b) Chylomicrons. The increase in liver lipid labeling of alcohol-fed rats after gastric intubation of labeled lipid was confirmed by a similar increase 3 hours after iv injection of chylomicron- ${ }^{14} \mathrm{C}(\mathrm{Ta}-$ ble IV). In the five pairs of these rats in which plasma triglyceride was measured, its concentration and specific activity were not found to be significantly affected by ethanol (Table IV).

In contrast to the liver lipid labeling 3 hours after the chylomicron injection, labeling of total hepatic lipids 10 minutes after iv chylomicron administration was not significantly affected by ethanol; the mean values were $40,011 \mathrm{dpm}$ per $\mathrm{g}$ with ethanol and $37,921 \mathrm{dpm}$ per $\mathrm{g}$ in the controls (nine pairs of rats, $\mathrm{p}>0.5$ ). This suggested that 
the hepatic clearing from the blood of chylomicrons or chylomicron breakdown products was not altered by ethanol, a finding supported by studies of disappearance rate of intravenously injected chylomicrons, which was found to be unaffected (Figure 4$)$.

\section{Discussion}

Theoretically, fatty acids that accumulate in hepatic triglycerides can originate primarily from three major sources: the diet, the adipose tissue stores, and fatty acids synthesized in the liver itself. Our observations indicate that, depending upon the experimental conditions of alcohol administration, each of these three sources plays a major role.

After a single large dose of alcohol, hepatic triglycerides increased and their fatty acids resembled those of adipose tissue (Table II), confirming the work of others $(8,24)$. The pathogenesis of this type of fatty liver, however, remains the subject of debate, the concept of enhanced peripheral

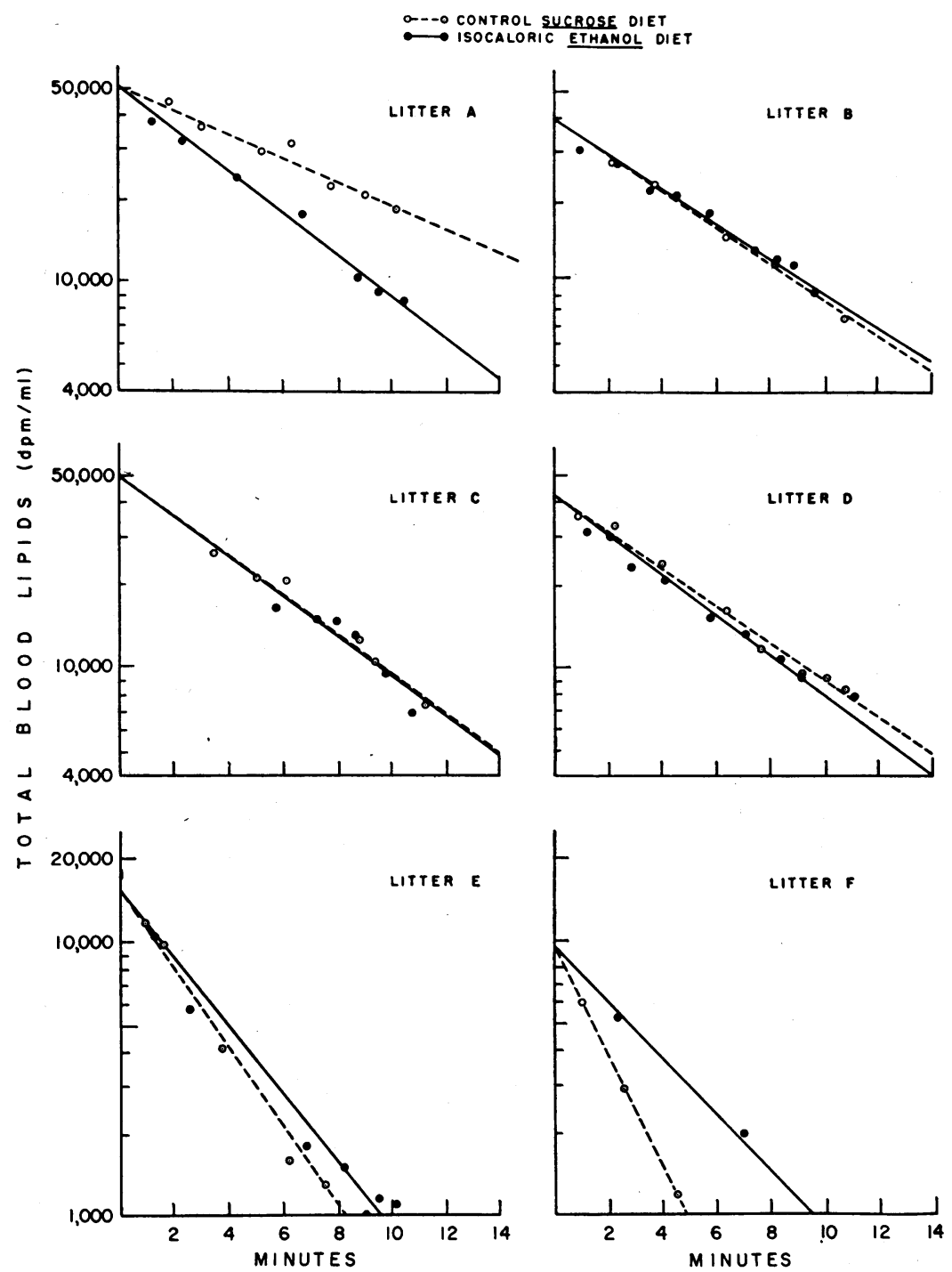

Fig. 4. Comparison of the Clearance Rate of ChYlomicrons $-{ }^{14} \mathrm{C}$ adminisTERED INTRAVENOUSLY IN SIX PAIRS OF RAT LITTERMATES FED WITH THE SUCROSE CONTROL DIET OR ISOCALORIC AMOUNTS OF THE ETHANOL DIET. Chylomicrons were obtained by thoracic duct cannulation in litters $\mathrm{A}$ to $\mathrm{D}$ and by the method of Green and Webb (14) in litters E to F. 
fat mobilization (8) being opposed by data that support the possibility of a decrease in the hepatic metabolism of fatty acids mobilized from adipose tissue at a normal rate (25).

Our study underscores several differences in hepatic lipids between the administration of a single large dose of ethanol or glucose (Table II) and prolonged intake (Figure 1). After a single dose of ethanol, steatosis was generally moderate compared to that of prolonged intake, especially in male rats. There was also a difference in hepatic lipids among the various control groups, with the lowest values in the acute experiments; these low values, which are within the range of those obtained by others under similar experimental conditions (24), may be related to the fasting of the rats before the experiment. It has indeed been shown that hepatic triglycerides of fasting rats are lower than those of fed rats (26). Among the control rats of the chronic experiments, the highest hepatic lipid values were observed in the low-fat group (Figure 1), which is possibly related to the high carbohydrate content of the low-fat diet, as diets rich in carbohydrate have been reported to increase hepatic lipids (27). After prolonged ethanol intake, in contrast to the effect of a large single dose of ethanol, the composition of the fat accumulated in the liver was strikingly different from that of adipose tissue (Figures 2 and 3 ). Prolonged ethanol intake when given with fat-containing diets was found to result in the hepatic accumulation of fatty acids resembling, in part, dietary lipids (Figure 3 ). To explain this finding, several possible mechanisms were investigated. Increased lipid absorption could not be implicated, and hepatic chylomicron uptake was also found to be unaffected by ethanol as measured by hepatic lipid labeling 10 minutes after intravenous chylomicron injection. In contrast, greater hepatic lipid labeling was found both 3 hours after intravenous chylomicron- ${ }^{14} \mathrm{C}$ injection and 2 to 6 hours after oral palmitate- ${ }^{3} \mathrm{H}$ administration, suggesting that ethanol in some way interferes with the hepatic metabolism of lipids (Tables III and IV). Whether under normal circumstances the liver metabolizes circulating chylomicrons per se or whether these are first hydrolyzed in the vascular space or in peripheral tissues is the subject of some controversy (28-30). Consistent with the latter possibility is our observation of a similarity between circulating free fatty acids and dietary fatty acids in rats given oil-containing diets.

The biochemical step and the mechanism through which ethanol interferes with the metabolism of lipids in the liver have not been elucidated in the present study. Decreased release of lipoproteins from the liver has been proposed as a mechanism for the fatty liver produced on carbon tetrachloride intoxication (31), and on the the basis of data obtained in vitro with perfusion of livers and large amounts of alcohol it has also been suggested that this may play a role in the pathogenesis of the alcoholic fatty liver (32). It has been shown, however, that both in man $(3,10,33,34)$ and in rats (35) large doses of alcohol produce an increase of circulating blood lipids, at least during the initial period of intoxication, lasting up to 2 weeks $(33,34)$. The triglyceride rise coincided with the development of the fatty liver (33). These observations, as well as those obtained with more moderate amounts of alcohol, which lead to fatty liver production in man without fall of plasma triglycerides (3), and the present data, which show no decrease of plasma triglyceride concentration or specific activity after chylomicrons $-{ }^{14} \mathrm{C}$ injection (Table IV), suggest indirectly that decreased hepatic release of lipoproteins does not play a primary role in the pathogenesis of the fatty liver produced by the prolonged ingestion of alcohol. Our previous observation (36), confirmed by others (37), that ethanol decreases the hepatic ${ }^{14} \mathrm{CO}_{2}$ production from palmitate- ${ }^{14} \mathrm{C}$, brings up another hypothesis for the pathogenesis of the alcoholic fatty liver, namely, decreased hepatic lipid oxidation. The reduction by ethanol of ${ }^{14} \mathrm{CO}_{2}$ production from palmitate- ${ }^{14} \mathrm{C}$ was paralleled by a similar decrease in ${ }^{14} \mathrm{CO}_{2}$ evolved from acetate${ }^{14} \mathrm{C}$ (36), which suggests that the decrease in fatty acid oxidation may result from decreased citric acid cycle activity. Such a mechanism would offer a satisfactory explanation for the hepatic accumulation of fatty acids resembling dietary lipids, whether these fatty acids derive directly from chylomicrons cleared by the liver itself or whether they originate from chylomicrons hydrolyzed in peripheral tissues.

That dietary fat represents an important source for the fatty acids of the alcoholic fatty liver is indicated not only by the nature of the fatty acids accumulating in the liver (Figure 3 ), but also by 
the fact that littermates given the same amount of alcohol developed less steatosis when most of the fat in the diet had been replaced isocalorically by sucrose (Figure 1). Similar results were obtained in human volunteers given ethanol with either lowfat or fat-containing diets (38).

On prolonged intake of ethanol and low-fat diets, the fatty acids accumulating in hepatic triglycerides were also different from adipose tissue fatty acids, with $50 \%$ more palmitate, but a linoleate concentration only one-fifth that of adipose tissue (Figure 2). The difference in linoleate content is especially significant, as linoleate cannot be synthesized by mammalian tissues and therefore represents an excellent depot fatty acid marker.

Despite the difference in composition between liver and adipose tissue fatty acids, liver fatty acids could possibly have derived from adipose tissue through a process of selective FFA mobilization, for instance, from an active but small adipose tissue subcompartment. This is unlikely, however, in the case of the fatty liver produced by prolonged intake of alcohol and fat-free diets, since fatty acids of liver triglycerides differed not only from adipose fatty acids but also from circulating FFA. The latter had a linoleate content more closely resembling total adipose tissue stores than liver triglycerides (Figure 2). Theoretically, a difference in the rate of hepatic metabolism of the various fatty acids could also lead to a difference in composition between liver and adipose tissue, though the fatty acid may originate from the depots. That such a factor, however, plays only a minor role is suggested by the fact that when fatty liver is produced through enhanced peripheral fat mobilization, after epinephrine for instance, fatty acids accumulating in the liver do indeed resemble adipose tissue (39). Barring the unlikely possibility that ethanol enhances selectively the oxidation of linoleate in the liver, the fact that the linoleate content of the fatty liver produced by ethanol and low-fat diets was one-fifth that of adipose tissue suggests that a large component of the fatty acids originated in the liver itself rather than from adipose stores. This underlines the role of hepatic lipogenesis as the source for the fatty acids in the fatty liver produced by prolonged intake of alcohol and low-fat diets. These fatty acids could accumulate locally because of decreased fatty acid oxidation $(36,37)$, enhanced fatty acid (36) and tri- glyceride $(24,35)$ synthesis, or a combination of these mechanisms.

\section{Summary}

In rats, one large dose of ethanol $(7.5 \mathrm{~g}$ per $\mathrm{kg})$ produced moderate hepatic accumulation of fatty acids resembling those of adipose tissue; in contrast, after prolonged ethanol intake, fatty liver was more pronounced and had a fatty acid composition different from depot fats.

Rats given 24 days of ethanol with low-fat diets ( $2 \%$ of calories) had a linoleate concentration in hepatic triglycerides one-fifth that of adipose tissue with, however, $50 \%$ more palmitate, an endogenously synthesized fatty acid.

In rats given alcohol with fat-containing diets ( $43 \%$ of calories), fatty acids accumulating in the liver triglycerides had a large component of dietary fatty acids (either laurate plus myristate or linolenate), whereas these fatty acids when administered to "prelabel" adipose tissue were found to be much less abundant in liver triglycerides than in depots.

Despite the same ethanol intake, significantly less steatosis developed in rats given isocaloric diets containing carbohydrate instead of fat. After 24 days, the rise in total hepatic lipids was 1.5 -fold on the $2 \%$ fat diet compared to 2.6 -fold on the $43 \%$ fat diet; corresponding triglyceride changes were 2.6 - and 6.3-fold respectively.

Whereas ethanol had no apparent effect on intestinal palmitate ${ }^{-14} \mathrm{C}$ absorption or uptake by the liver of chylomicron- ${ }^{14} \mathrm{C}$ administered intravenously, hepatic lipid labeling was enhanced 2 to 6 hours after palmitate $-{ }^{14} \mathrm{C}$ intubation or 3 hours after chylomicron $-{ }^{14} \mathrm{C}$ injection.

These studies indicate that the source and the magnitude of the fatty acids accumulating in hepatic triglycerides after alcohol administration depend on the dose and duration of alcohol intake as well as the fat content of the associated diet.

\section{Acknowledgment}

We are grateful to Dr. T. P. Almy for his continuous interest and support.

\section{References}

1. Lieber, C. S., and N. Spritz. Dietary, adipose tissue and newly synthesized fatty acids in the pathogene- 
sis of the fatty liver produced by prolonged ethanol intake (abstract). Gastroenterology 1965, 48, 500.

2. Best, C. H., W. S. Hartroft, C. C. Lucas, and J. H. Ridout. Liver damage produced by feeding alcohol or sugar and its prevention by choline. Brit. med. J. 1949, 2, 1001.

3. Lieber, C. S., D. P. Jones, and L. M. DeCarli. Effects of prolonged ethanol intake: production of fatty liver despite adequate diets. J. clin. Invest. 1965, 44, 1009.

4. Klatskin, G. Alcohol and its relation to liver damage. Gastroenterology 1961, 41, 443.

5. Lieber, C. S., and C. S. Davidson. Some metabolic effects of ethyl alcohol. Amer. J. Med. 1962, 33, 319.

6. Lieber, C. S. Pathogenesis of hepatic steatosis. Gastroenterology 1963, 45, 760.

7. Isselbacher, K. J., and N. J. Greenberger. Metabolic effects of alcohol on the liver. New Engl. J. Med. 1964, 270, 351.

8. Horning, M. G., E. A. Williams, H. M. Maling, and B. B. Brodie. Depot fat as source of increased liver triglycerides after ethanol. Biochem. biophys. Res. Commun. 1960, 3, 635.

9. Lieber, C. S., C. M. Leevy, S. W. Stein, W. S. George, G. R. Cherrick, W. H. Abelmann, and C. S. Davidson. Effect of ethanol on plasma free fatty acids in man. J. Lab. clin. Med. 1962, 59, 826.

10. Jones, D. P., M. S. Losowsky, C. S. Davidson, and C. S. Lieber. Effects of ethanol on plasma lipids in man. J. Lab. clin. Med. 1963, 62, 675.

11. Jones, D. P., E. Perman, and C. S. Lieber. Decreased circulating free fatty acid turnover after ethanol ingestion in man. J. Lab. clin. Med. 1965, 66, 804.

12. Mohrhauer, H., and R. T. Holman. The effect of dose level of essential fatty acids upon fatty acid composition of the rat liver. J. Lipid Res. 1963, 4, 151.

13. Farquhar, J. W., W. Insull, P. Rosen, W. Stoffel, and E. H. Ahrens, Jr. The analysis of fatty acid mixtures by gas-liquid chromatography. Nutr. Rev. 1959, 17 (suppl.), 1.

14. Green, C., and J. A. Webb. The uptake of chylomicron fatty acids by isolated liver cells. Biochim. biophys. Acta (Amst.) 1964, 84, 404.

15. Bollman, J. L., J. C. Cain, and J. H. Grindlay. Techniques for the collection of lymph from the liver, small intestine, or thoracic duct of the rat. J. Lab. clin. Med. 1948, 33, 1349.

16. Felts, J. M. Personal communication.

17. Folch, J., M. Lees, and G. H. Sloane Stanley. A simple method for the isolation and purification of total lipide from animal tissues. J. biol. Chem. 1957, 226, 497.

18. Dole, V. P. A relation between non-esterified fatty acids in plasma and the metabolism of glucose. J. clin. Invest. $1956,35,150$.
19. Van Handel, E., and D. B. Zilversmit. Micromethod for the direct determination of serum triglycerides. J. Lab. clin. Med. 1957, 50, 152.

20. Goldrick, B., and J. Hirsch. A technique for quantitative recovery of lipids from chromatoplates. J. Lipid Res. 1963, 4, 482.

21. Metcalfe, L. D., and A. A. Schmitz. The rapid preparation of fatty acid esters for gas chromatographic analysis. Analyt. Chem. 1961, 33, 363.

22. Spritz, N. Effect of fatty acid saturation on the distribution of the cholesterol moiety of very low density lipoproteins. J. clin. Invest. 1965, 44, 339.

23. Snedecor, G. W. Statistical Methods, 5th ed. Ames, Iowa, Iowa State College Press, 1956.

24. Scheig, R., and K. J. Isselbacher. Pathogenesis of ethanol-induced fatty liver: III In vivo and in vitro effects of ethanol on hepatic fatty acid metabolism in rat. J. Lipid Res. 1965, 6, 269.

25. Poggi, M., and N. R. Di Luzio. The role of liver and adipose tissue in the pathogenesis of the ethanolinduced fatty liver. J. Lipid Res. 1964, 5, 437.

26. Göransson, G., and T. Olivecrona. The metabolism of fatty acids in the rat. I. Palmitic acid. Acta physiol. scand. 1964, 62, 224.

27. MacDonald, I. Some influences of dietary carbohydrate on liver and depot lipids. J. Physiol. (Lond.) 1962, 162, 334.

28. Olivecrona, T., E. P. George, and B. Borgström. Chylomicron metabolism. Fed. Proc. 1961, 20, 928.

29. Morris, B. The metabolism of free fatty acids and chylomicron triglycerides by the isolated perfused liver of the rat. J. Physiol. (Lond.) 1963, 168, 564.

30. Felts, J. M., and P. A. Mayes. Lack of uptake and oxidation of chylomicron triglyceride to carbon dioxide and ketone bodies by the perfused rat liver. Nature (Lond.) 1965, 208, 195.

31. Recknagel, R. O., B. Lombardi, and M. C. Schotz. A new insight into pathogenesis of carbon tetrachloride fat infiltration. Proc. Soc. exp. Biol. (N. Y.) 1960, 104, 608

32. Schapiro, R. H., G. D. Drummey, Y. Shimizu, and K. J. Isselbacher. Studies on the pathogenesis of the ethanol-induced fatty liver. II. Effect of ethanol on palmitate-1- $\mathrm{C}^{14}$ metabolism by the isolated perfused rat liver. J. clin. Invest. 1964, 43, 1338.

33. Lieber, C. S., D. P. Jones, J. Mendelson, and L. M. DeCarli. Fatty liver, hyperlipemia and hyperuricemia produced by prolonged alcohol consumption, despite adequate dietary intake. Trans. Ass. Amer. Phycns 1963, 76, 289.

34. Schapiro, R. H., R. L. Scheig, G. D. Drummey, J. H. Mendelson, and K. J. Isselbacher. Effect of prolonged ethanol ingestion on the transport and metabolism of lipids in man. New Engl. J. Med. 1965, 272, 610.

35. Horning, M. G., M. Wakabayashi, and H. M. Maling. Biochemical processes involved in the synthesis, 
accumulation and release of triglycerides by the liver in Mode of Action of Drugs. Effects of Drugs on Synthesis and Mobilization of Lipids, E. C. Horning, Ed. Oxford, Pergamon, 1963, vol. 2, p. 13.

36. Lieber, C. S., and R. Schmid. The effect of ethanol on fatty acid metabolism; stimulation of hepatic fatty acid synthesis in vitro. J. clin. Invest. 1961, 40, 394.

37. Rebouças, G., and K. J. Isselbacher. Studies on the pathogenesis of the ethanol-induced fatty liver. I.
Synthesis and oxidation of fatty acids by the liver. J. clin. Invest. 1961, 40, 1355.

38. Lieber, C. S., and N. Spritz. Ethanol-induced fatty liver on fat-free and fat-containing diets: role of dietary, adipose, and endogenously synthesized fatty acids (abstract). J. clin. Invest. 1965, 44, 1069.

39. Feigelson, E. B., W. W. Pfaff, A. Karmen, and D. Steinberg. The role of plasma free fatty acids in development of fatty liver. J. clin. Invest. 1961, 40, 2171. 